\title{
New Tomato (Solanum lycopersicum) Hybrids Obtained at V.R.D.S. Buzău
}

\author{
Bianca ZAMFIR ${ }^{1 *}$, Dorel HOZA², Costel VÎNĂTORU ${ }^{1}$, Camelia BRATU ${ }^{1}$, \\ Elena BARCANU ${ }^{1}$
${ }^{1}$ Vegetable Research and Development Station Buzău, 23 Mesteacănului Str, 120024 Buzău, Romania
${ }^{2}$ University of Agronomic Sciences and Veterinary Medicine of Bucharest, 59 Marasti Blvd, , 011464
Bucharest, Romania
*Corresponding author, e-mail: zamfir_b@yahoo.com

Bulletin UASVM Horticulture 74(2)/ 2017

Print ISSN 1843-5254, Electronic ISSN 1843-5394

DOI:10.15835/buasvmcn-hort: 0027

\begin{abstract}
V.R.D.S. Buzău is well known in tomato breeding. Here we present, for the first time in Romania, commercial hybrid seeds. The first batch of hybridization were made up of accession $10 \mathrm{x}$ Bizon, Bulgarian origin hybrid followed by 24-13 accession (obtained by C. Petrescu, USAMV Bucharest) x Temnocrasnei resulting Export II hybrid. Since 1996 was obtained the first tomato hybrid in this station and it was registered in the Official Crop Plants Catalogue and sold as Siriana F1.
\end{abstract}

Keywords: breeding, genotypes, heterosis, hybridization, Siriana

\section{Introduction}

Opeña et al. (2001) indicate that hybrid tomato varieties have many advantages compared to open-pollinated varieties. Hybrids usually produce higher yields. They generally mature earlier and more uniformly. Many hybrids have better fruit quality and disease resistance.

Nowadays, in our country, $90 \%$ of greenhouse crops are set up with foreign hybrids. As a result of consumers pressure on growers who want to consume autochthonous tomatoes recognized for their special taste and flavor, research has been intensified at VRDS Buzău to address this need. Determining the diversity of the germplasm collection and the intergenetic relationships of the breeding material is of great help in building a crop improvement strategy. (Vinătoru, 2008).

$\mathrm{F}_{1}$ hybrids are widely used as greenhouse crops, as they have superior characteristics in terms of productivity, quality and genetic resistance to the attack of pathogens compared to varieties. Intercrossing different varieties of plants frequently produces hybrid offspring with superior vigor and increased yields, in a poorly understood phenomenon known as heterosis. (Krieger et al., 2010)

\section{Aims and Objectives}

The research aims 4 main stages as follows: Stage I aimed to establish and continuously enrich the germplasm collection in this species; Stage II - evaluation of the germoplasm collection and its distribution on fields and breeding phases; Stage III - introducing valuable genotypes into intensive breeding process; Stage IV- exploiting the germoplasm collection by obtaining new F1 hybrids manifesting reproductive, metabolic and adaptive heterosis.

\section{Materials and Methods}

The genetic material involved in the study consisted of 1524 genotypes, a special emphasis being placed on the old, native cultivars, with valuable attributes for the breeding process, represented in particular by taste and aroma. The genotypes stabilized as a result of breeding process were involved in testing of general and specific combining ability. To test the general and specific 


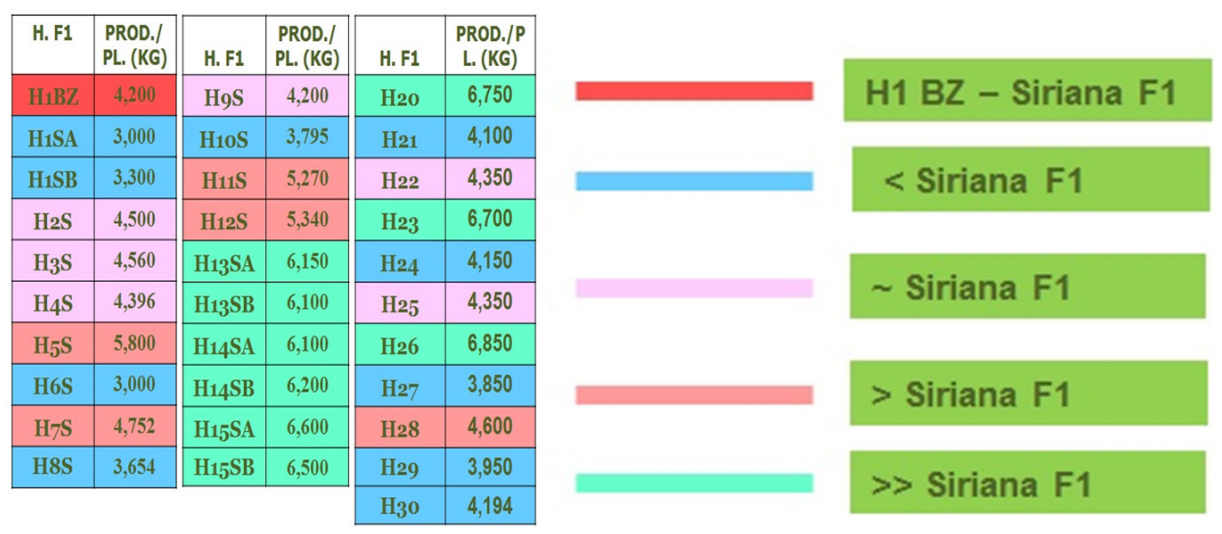

Fig.1. Hybrid combinations that manifested heterosis phenomenon

combining ability we used the tester genitors the SP+ lines: L 19, L 24 x13, L 165, L 23 sp lines: L 10, L 22, L 46, L 50, L 66 and L 67. 'Siriana' $F_{1}$ hybrid was used as control variety in the experience for the evaluation of the new obtained hybrids.

\section{Results and Discussions}

The germplasm collection was structured according to the breeding stage on 3 groups: $\mathrm{SP}+$ (indetermined lines) - 887 lines from which 326 stable lines (S), A (advanced) - 253 and Sg (segregant) - 308, SP (semi-determinate) - 296 lines from which 91 S, A-78 and 127 Sg, Sp-(selfprunning) - 341 lines from which 112 S, $98 \mathrm{~A}$ and $131 \mathrm{~S}$.

Results obtained after general combining ability test: from $326 \mathrm{SP}+$ stable genotypes only 182 passed the general combining ability test; from 91 SP only 38 passed and from 112 stable sp genotypes only 57 passed.

Results obtained after specific combining ability test: from 66248 hybrid possible combinations at SP + genotypes only 642 were made; from 2888 hybrid possible combinations at SP genotypes only 86 were made and from 6498 hybrid possible combinations at $\mathrm{sp}$ genotypes only 184 were made.

Valuable hybrid combinations obtained after testing general and specific combining ability: 30 hybrid combinations manifested visible reproductive, somatic, adaptive and metabolic heterosis phenomenon. These are encoded as: H1
$\mathrm{Bz}, \ldots \mathrm{H} 30 \mathrm{Bz}$. In order to demonstrate the stability and uniformity of the genitors and the degree of compatibility between them and the uniformity of hybridization results, the hybridization process has been repeated for 6 years. 'Siriana' $F_{1}$ hybrid was used as control variant in the experiments (Fig.1).

\section{CONCLUSION}

Research has been completed with the creation of a valuable germplasm collection consisting of 1524 genotypes grouped according to the degree of genetic stability on 3 groups: stable, advanced and segregant;

General and specific combining ability test was made at the stable genotypes and 529 genotypes passed the test.

30 hybrid combinations manifested the heterosis phenomenon and nine of them recorded significantly higher production than the control hybrid. Starting in 2017, valuable hybrids will be patented at ISTIS and proposed for approval and also extended as vegetable crop.

\section{REFERENCES}

1. Krieger U, Lippman ZB, and Zamir D (2010). The flowering gene SINGLE FLOWER TRUSS drives heterosis for yield in tomato. Nature genetics 42: 459-463.

2. Opeña RT, Chen JT, Kalb T and Hanson P (2001). Hybrid Seed Production in Tomato, International Cooperators Guide, AVRDC pub \# 01-527

3. Vinatoru C (2008) Metode de ameliorare a plantelor de cultura, Editura Gama Design, ISBN 978-973-881-30-0-7 